\title{
STYLES AND LEARNING RESULTS FORMATION OF PGSD STUDENTS IN THE LECTURE OF LEARNING ELEMENTARY SCHOOL PROBLEMS IN EVEN SEMESTER 2016/2017 STATE UNIVERSITY MALANG
}

\author{
I Made Suardana \\ Universitas Negeri Malang, Indonesia \\ Email:
}

\begin{abstract}
In the lecture of "problems of learning in elementary school" is one of the mandatory subjects for PGSD undergraduate students. This course expects students to (1) show their own performance, qualified and measurable to examine the implications of development or the implications of science, technology or art that elicits learning problems in elementary schools (SD/ MI) which oriented on Active Creative Effective Fun ICT-based learning (PAKEM BATIK). (2) Master the rules and scientific ethics agree with the method of science to determine the problems of the learning system in SD/MI which oriented on PAKEM $B A T I K$. This research purpose to describe styles and learning result formation of PGSD students. The method used descriptive qualitative. The result, there are 6 styles and learning result formation of PGSD student based on the gradation of learning skill with meaning related to observing, asking, trying, reasoning, giving, and creating.
\end{abstract}

Keywords: problems, learning in elementary school, performance, qualified, and measurable

\section{INTRODUCTION}

Based on the spontaneous complaints expressed by a number of lecturers and researchers after being PGSD lecturers since 1991 when they lecture various subjects found that students of PGSD in UM, especially in the odd semester of $2016 / 2017$ ago, there are $50 \%$ of active students in lectures. Especially on certain occasions after the lecturer gives an explanation and or after a certain group who presents the work of the group to a material.

Lecturers/moderators give the opportunity to ask the audience about something has been discussed/presented, but it seems that the students do not ask questions without being asked/motivated to ask (as if the lecturer/group explanation is very clear or clear enough for all students) (Faure, 1980). In this case, the lecturers motivate students to ask that what has been discussed can be expanded/clarified again (after being motivated, then there are 1 to 3 students ask the question to the lecturer or to members of the group who have presented the material given by the lecturer, although they still have to wait between 5-10 minutes).
The student's question can be addressed to the lecturer and/or to the members of the group presentation who present the material, then the lecturer offered to the student who did not ask to answer the question, it is rarely the one who will answer promptly right (without being motivated before by the lecturer), because in a relatively long time, there are no student has the initiative to answer, then the lecturer should motivate again and give answer clue from the possible answer to each question; for a few minutes (approximately 5-10 minutes) there are students who want to answer the questions. Suppose there are 1 to 3 students who want to answer but the answer often is not correct as described by the lecturer and or group that present problems in elementary school learning material at the time.

The material of problems of learning in elementary school is one of the compulsory subjects for PGSD students of the undergraduate program. This course expects students to (1) show their own performance, qualified and measurable to examine the implications of development or the implications of science, technology or art that raises the problems of learning in SD / MI which oriented on Active Creative Effective Fun ICT- 
based learning (PAKEM BATIK). (2) master the procedures and scientific ethics agree with the scientific method to determine the problems of the learning system in SD / MI which oriented on PAKEM BATIK. (Wiyono, 2016).

Firstly, the subject matter of problems of learning in the elementary school is expected PGSD students to achieve the learning outcomes as set in KKNI to improve the quality of lecturing courses in the subjects of better learning problems in elementary school. Secondly, improving the quality of teachers in elementary schools will thus have a broad impact on the quality of elementary school graduates. In accordance with KKNl learning achievement deals with the PGSD study program in education (pedagogical) as follows: (1) Apply the field of science and technology in the field of education, in developing learning tools in accordance with elementary school curriculum (SD/MI), (2) carry out educational learning in elementary school, (3) master the theoretical concepts in the field of student characteristics in general, elementary students in depth and able to formulate problem solving of elementary students' characteristics procedurally, (4) master learning theories and learning principles that educate and able to formulate problem solving learning and procedural areas procedurally, (5) apply science and technology of elementary school education and communication technology and information for learning purposes, (6) facilitate the development of potential students in actualizing various potentials, (7) apply science and technology aspects of elementary education to communicate effectively empathic and courteous to students, (8) carry out process assessment and learning outcomes, (9) utilize the assessment results for learning purposes, (10) perform reflective actions in order to improve the quality of learning, (11) make transactional decisions in the elementary school subject to the developing situation. (12) Take responsibility for the work and be responsible for the achievement of school work.

Understanding the world of education varies for everyone depending on the background and goals to be achieved. From these many possibilities, there are four definitions of learning as suggested by experts in Rusyan and Daryani S (1990: 5) (1) "Learning is a modification, or reinforcing behavior through experience, (2) a process of changing individual behavior through interaction with the environment " (3) learning in a broad sense is a process of behavioral change expressed in the form of deeds. " From 3 meanings mentioned above, learning can be concluded that learning is an individual activity to process, reconstruct past experiences with new experiences in such a way as to achieve certain learning objectives that are permanent.

Students learning style is very influential on the achievements they get. The more appropriate the learning style developed by the student, the higher the achievement he will gain and vice versa. Student learning style or student learning style can be interpreted as the cognitive, affective, and psychological characteristics of a student learning about how he or she understands, interacts and responds to the learning environment, which is unique and relatively stable.

There are at least 7 learning styles that are very commonly developed by DePorter and Hernacki, 2005: 110) there are 3 learning styles of the students, even for students studying in college, namely: First, Visual (Visual Learners) visual learning style (Visual Learners) focuses on the visual acuity. That is, concrete evidence must be shown in advance so that the learners understand. This style of learning rely on sight or preview the evidence then it can be able to believe. There are some characteristics for students who like this visual learning style, that is: (1) the need to see something (information/lessons) visually to know it or understand it, (2) have a strong sensitivity to color, (3) have sufficient understanding of artistic problems, (4) have difficulties in direct dialogue, 5) too reactive to sound, (6) difficult to follow verbal suggestions, and to (7) often misinterpret words or utterances. The characteristics of visual learning styles include the following (Kolb, 1998) : (1) tend to see attitudes, movements, and lips of teachers/lecturers who are teaching/explaining the material, (2) not a good listener when communicating, (3) when given instructions to do something, usually will see other students and then he acts, (4) do not like to talk in front of the group and do not like to listen to others. Seen passive in discussion activities, (5) less able to remember information given orally, (6) prefers demonstrations rather than verbal explanations, and (7) can sit quietly in a noisy and crowded situation without being disturbed. 
Second, Auditory Learners. The auditory learning style relies on hearing to understand and remember something. Characteristics of this learning model actually put hearing as the primary tool for absorbing information or knowledge. That is, the learning process must listen, then he can remember and understand the information. There are several characteristics of this auditory style: students who have this learning style can only absorb all information through hearing, (2) have difficulties to absorb information in the form of writing directly, (3) have difficulty writing or reading. The characteristics of the auditory learning style are: (1) Able to remember well the explanation of teacher / lecturer, or the material discussed in the group / class, (2) the master of the listener: it is easy to master the advertisement/ song on television/radio, (3) tend to be a lot of talking, (4) dislike to read and generally is not a good reader because less able to remember well what he just read, (5) less skilled in doing writing tasks, (6) be happy to discuss and communicate with people (7) are less interested in observing new things in the surrounding environment, such as the presence of a new student, or a bulletin board in the corner of the classroom.

Third, Kinesthetic (Kinesthetic Learners). Kinesthetic learning styles require the individual touches something that provides certain information so that he can remember it. Of course, there are some characteristics of this learning model that not everyone can do. The first character is to place the hand as the primary receiving device in order to keep it in mind. Just by holding it, someone who has this style can absorb information without reading the explanation. The characteristics of the kinesthetic learning style are: (1) Touch everything that he encounters, including learning, (2) difficult to keep quiet or sit, always want to move, (3) work on everything that enables his hands to be active. Example: when the teacher explains the lesson, he listens while his hands are engrossed in a drawing, (4) like to use real objects as learning tools, (5) difficult to master abstract things like maps, signs and symbols, (6) love to practice and (7) like games and physical activity.

\section{METHODS}

This research employs descriptive qualitative research method that researcher will describe or draw the data with the words systematically, straightforward, and rational, accurate about the facts, properties, and the relationship among the phenomena that were studied. As stated by Moleong (2007: 11) that the research report will contain data citations to illustrate the presentation of the report. The data may come from interviews, field notes, photographs, videotapes, documents, notes or memos, and other official documents".

The data sources from this study consist of the main data source and the additional data source referred to as "main data source is the words and actions" by the subjects studied, the rest is additional data such as documents (Lofland and Lofland in Moleong, 2007: 157). Other primary and secondary data sources. Sugiyono (2015: 225) "primary sources are data sources that directly provide data to data collectors and secondary sources are data sources that do not directly provide data to data collectors: for example through others or through documents relating to this research problem.

Data analysis by Bogdan and Biklen (Moleong 2007: 248) Data analysis is the effort to process the data, synthesize the data, seek and identify patterns, find what is important and what is learned, and decide what can be characterized to others " related to a particular research problem in this case the relationship of learning styles to learning outcomes in the lecture of problems of learning in elementary school in even semester 2016/2017 PGSD student of State University of Malang.

\section{Research Procedures}

As for the stages of this qualitative research in data collection, there are 4 basic steps, namely: (1) field notes based on observations, (2) journal diaries, (3) important event notes from the field, and (4) photos and video recordings "(Patilima, 2005: 88) character education activities.

Qualitative research procedure is based on inductive thinking logic, so that the research planning is very flexible, qualitative research must go through stages and research procedures that have been determined. The first thing to do before beginning the entire stage of qualitative research is to establish the research question which in the qualitative research referred as the focus of research, that is the question of things to 
be sought for answers through the research.

\section{Setting and Research Subject Setting}

Research settings in this research are very important and have been determined when putting the focus on research. Setting and research subject is a unity that has been determined from the beginning. This research setting shows the communities to be studied and at the same time their physical and social conditions. In qualitative research, research settings will show the location of research directly attached to the focus of research that has been established since the beginning. The setting of this research cannot be changed unless the focus of his research is changed, in this case is conducted in the State University of Malang in PGSD department, even semester year 2016/2017 upon the lecture of learning problems in Elementary School.

\section{Research Subject}

Research subjects that have been reflected in the focus of research are determined deliberately. The subject of this research became informants who will provide various information needed during the research process. Informants of this research include several kinds, such as: (1) key informants, those who know and have the various basic information needed for the research. (2) key informants, those who directly visible in the social interactions studied, (3) additional informants, those who can provide information although not directly involved in the social interactions studied. In this case is 73 students of the State University of Malang in the department of PGSD even semester, year 2016/2017 on subjects of learning problems in Elementary School.

\section{Data Collection, Data Processing, and Data Analysis}

Collection, processing, and data analysis are performed simultaneously during the research process. In qualitative research, data processing should not be done after data collection, or data analysis is not absolutely done after data processing is completed. In this case, while data is collected, the researcher can process and perform data analysis simultaneously. Conversely, when analyzing the data, the researcher can return to the field again to obtain additional data that is considered necessary and process it again.

Data processing is done by clarifying or categorizing data based on several times face to face according to the focus of research. If the research is to form propositions or theories, then inductive data analysis can be done through several stages, as done by (Taylor and Bogdan, 1984: 127) in grounded research as follows: (1) Making a temporary definition of the learned symptom , (2) Formulate a hypothesis to explain the phenomenon, (3) Study a case to see fit between case and hypothesis, (4) If the hypothesis is not formulated the case, reformulate hypotheses of learned symptoms, (5) study negative cases to reject the hypothesis, (6) When encountered a negative case. re-formulate the hypothesis of symptoms, (7) Continue until the hypothesis is actually accepted by testing the varied cases.

\section{RESULTS AND DISCUSSION \\ Result}

The results of this study can be described as follows: Based on the gradation of learning the skill with meaning related to "observing, asking, trying, reasoning, giving and creating from 73 students who have observation skill in their study consecutively are 51,11, 9,1,1,0 students; as the first and so forth from the other 6 skill models, asking are $8,16,28,16,4,1$ students; trying are $18,20,14,19,2,0$; reasoning are $4,12,16$, $22,10,9$; presenting are $0,4,2,12,36,19$; and creating are $0,0,6,4,18,45$. The learning results can be summarized not all directly proportional to the order of skills possessed by each student.

\section{Discussion}

In accordance with qualitative research procedures "field notes based on observations, (2) diary of the researcher, (3) important event notes from the field, and (4) photos and video recordings" Based on the gradation of student learning model skill with meaning related to " observing (visual), questioning (question), trying (experiment), reasoning (rational), presenting (displied), and creating (construct) of 73 students who have a model of learning skill in observing 
their study in order are 51, 11, 9, 1, 1, 0 students; this means that from 73 students who follow the subjects of problems of learning in elementary school as the subject of this study, they get knowledge, affective and or psychomotor based on observations in $\%=69.863$ compared to 15.068,12.328,1.369,1.369 and as the easiest first and so on from 6 other skill models, asking are 8 , $16,28,16,4,1$ students in $\%=10.958 ; 21.917$; $38.356 ; 21.917 ; 5.479 ; 1.369$. Trying are 18,20 , $14,19,2,0 ;$ in $\%=24.657 ; 27.397 ; 19.178 ; 26$, o27; 2.739; 0. Reasoning are 4, 12, 16, 22, 10, $9 ;$ in $\%=5.479 ; 16.438 ; 21.917 ; 30.136 ; 13.698$; 12.328. Presenting 0, 4, 2, 12, 36, 19; in $\%=0$; $5.479 ; 2.739 ; 16.438 ; 49.315 ; 26.027$. Creating are $0,0,6,4,18,45$. in $\%=0 ; 0 ; 8.219 ; 5.479$; $24.657 ; 61.643$.

Model of student learning style is varied in following the same subject from the same lecturer. But it can be understood that most of the students are easier, and/or their learning model is $69.863 \%$ as the biggest first choice asking is 38.356 as the third largest choice, trying is 27.397 as the second largest choice, reasoning is 30.136 as the fourth largest choice, presenting is 49,315 as the fifth largest choice, and creating is 61.643 of their last or sixth greatest choice.

Then it is quite clear that students have various learning style; very diverse, thus the lecturers are obliged to facilitate all models of student learning, facilitated appropriately for the more qualified graduates.

Students learning style is very influential on the achievements he gets (Degeng, 1998). The more appropriate the learning style developed by students, the higher the achievement he will gain and vice versa. Student learning style can be interpreted as the cognitive, affective, and psychological characteristics of the student learning about how he or she understands, interacts and responds to the learning environment, which is unique and relatively stable. There are at least 7 learning styles that are very commonly developed by DePorter and Hernacki, 2005: 110) there are 3 learning styles of students even until they study in college, namely: (1). Visual (Visual Learners), visual learning style focuses on the visual acuity. That is, concrete evidence must be shown in advance, so that the learners understand. This style of learning rely on sight or preview the evidence to believe it. There are some characteristics for students who like this visual learning style, namely: (1) need to see something (information/lesson) visually to know or understand it, (2) have a strong sensitivity to color, (3) have sufficient understanding of the artistic problem, (4) have difficulty in direct dialogue, (5) being too reactive to the sound, (6) difficult to follow verbal suggestions, and (7) often misinterpret words or utterances.

\section{CONCLUSION}

Student learning outcomes as the subject of this research can be concluded that not all outcomes are directly proportional to the order of skills possessed by each student.

Hence, there are various learning styles of the students in following the same courses from the same lecturer. But it can be seen that most students are easier by observing, and/or their learning model by observing that is $69.863 \%$ as the largest first choice, asking is 38.356 as the third biggest choice, trying is 27.397 as the second largest choice, reasoning is 30.136 as the biggest fourth choice, presenting is 49.315 as the fifth biggest choice, and creating is 61.643 as their last or sixth greatest choice.

Finally, no student has a model of creating as their first choice, a learning skill model like creating something is something difficult can be done without going through the other models and/or other five learning skills.

The researcher is fully aware that this journal still has weaknesses. Based on awareness, and humility, it is open to all parties to suggest constructive advice, so that the same weakness will not be repeated on another occasion; at least it can be minimized.

\section{REFERENCE}

Degeng, I Nyoman Sudana. 1998. Ilmu Pengajaran Taksonomi Variabel. Jakarta: Depdikbud Direktorat Dirjen Pendidikan Tinggi, Proyek Pengembangan Lembaga Pendidikan Tenaga Kependidikan.

DePorter, Bobby dan Hernacki. Mike. 2005. Quantum Leaming, (terjemah Alwiyah Abdurrahman) Membiasakan Belajar Nyaman dan Menyenangkan. Bandung: Kaifa 
Faure, Edgar, Herrera,Felipe; Kaddoura, Abdul, Raszzak; Lopes, Henri, Petrovsky, Arthur; Rahnema, Majid ; Ward, Frderick, Champion. 1980. Belajar Untuk Hidup, Dunia Pendidikan Hari Kini dan Hari Esok. Jakarta: Bratara Karya Aksara

Kolb, David. 1998. Student LearningStyle. New York: Mc Graw Hill Book Company.

Moleong, 2007. Metodelogi Penelitian Kualitalif. Bandung: PT Remaja Rosdakarya.

Rusyan, Tabrani \& S. Yani Daryani. Penuntun
Belajar Yang Sukses. Jakarta: Nine Karya Jaya.

Sugiyono. 2015. Metodelogi Penelitian Kualitatif. Bandung: Alfabeta.

Wiyono, Bambang, Budi. 2016 Kependidikan Sekolah Dasar dan Prasekolah, Katalog. FIP www.fip.um.ac.id 